\title{
Atypisk optikusnevritt
}

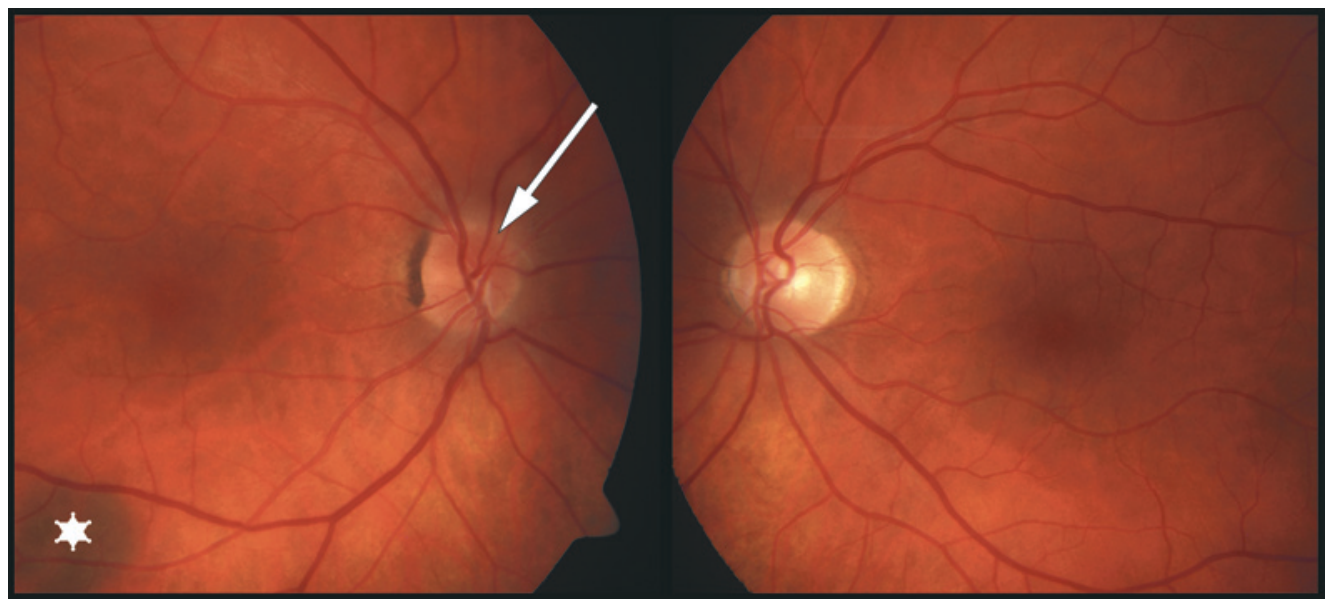

En mann i 50-årene oppsøkte øyelege grunnet gradvis synstap på høyre øye den siste måneden. Han hadde ingen ledsagende symptomer. I anamnesen kom det frem at pasienten var hivpositiv etter homoseksuell smitte, men fullt hivsupprimert på antiviral behandling.

Ved undersøkelse var visus på høyre øye 0,3 . Synsfeltundersøkelse av høyre øye viste redusert sensitivitet for lysstimuli, mest uttalt $i$ øvre nasale kvadrant. Høyre pupill reagerte sterkere på indirekte enn direkte lys, forenlig med relativ afferent pupilledefekt. Ved oftalmoskopi var høyre papille uskarpt avgrenset, lett hyperemisk og protruerende (pil). Temporalt ved papillen så man peripapillær pigmentering, som er en normalvariant. Som bifunn ble det funnet en nevus ved nedre høyre kararkade (stjerne). Visus, synsfelt og oftalmoskopi var normalt på venstre øye.

Klinisk forelå en høyresidig optikusnevropati. En typisk demyeliniserende optikusnevritt rammer unge voksne, oftere kvinner enn menn, er ensidig, debuterer akutt, har ledsagende smerter og bedres spontant. Avvik fra det typiske, såkalte røde flagg, tilsier målrettet utredning med tanke på annen bakenforliggende årsak (1). «Røde flagg» hos denne pasienten var alder, fravær av smerter, langsom utvikling og en anamnes- tisk mulighet for seksuell risikoatferd. Det ble startet utredning med tanke på bakenforliggende årsak (2). MR caput-undersøkelse var normal, uten demyeliniserende forandringer. Serologiske prøver viste syfilismarkører forenlig med aktiv infeksjon: IgM-test var positiv, og plasma reagin-titer var forhøyet. Spinalvæskeanalyse viste lett pleocytose og var svakt positiv for syfilisantistoffer.

På mistanke om infeksiøs optikusnevritt som følge av syfilisinfeksjon fikk pasienten i henhold til retningslinjene ved vår infeksjonsmedisinske avdeling penicillin 5 mill. IE $\times 4$ intravenøst i 14 dager. Pasienten opplevde rask bedring av synet. Etter 12 dagers behandling var visus på høyre øye 0,63 . Ved kontroll seks måneder senere var visus på høyre øye uforandret. Ved oftalmoskopi var høyre papille normal, mens synsfeltundersøkelse fortsatt viste lett reduksjon i sensitivitet for lysstimuli, mest uttalt i øvre nasale kvadrant.

Pasienten har gitt samtykke til at artikkelen blir publisert.

\section{Mari Kathrine Sand}

maksan@ous-hf.no

Tore Taksdal Stubhaug

Øystein Kalsnes Jørstad
Mari Kathrine Sand (f. 1984) er lege i spesialisering ved Øyeavdelingen, Oslo universitetssykehus, Ullevål.

Forfatter har fylt ut ICMJE-skjemaet og oppgir ingen interessekonflikter.

Tore Taksdal Stubhaug (f. 1984) er konstituert overlege ved Avdeling for mikrobiologi, Oslo universitetssykehus, Ullevål. Han jobber nå ved Mikrobiologisk avdeling, Sykehuset i Vestfold. Forfatter har fylt ut ICMJE-skjemaet og oppgir ingen interessekonflikter.

Øystein Kalsnes Jørstad (f. 1976) er spesialist i øyesykdommer og seksjonsoverlege ved Øyeavdelingen, Oslo universitetssykehus, Ullevål. Forfatter har fylt ut ICMJE-skjemaet og oppgir ingen interessekonflikter.

\section{Litteratur}

1. Weerasinghe D, Lueck C. Mimics and chameleons of optic neuritis. Pract Neurol 2016; 16: 96-110.

2. Boomer JA, Siatkowski RM. Optic neuritis in adults and children. Semin Ophthalmol 2003; 18: 174-80.

Mottatt 2.12. 2017, første revisjon innsendt 30.1. 2017, godkjent 23.3. 2017. Redaktør: Lars Frich. 